\title{
The Taxonomic Position of Saccoloma wercklei Christ
}

\author{
K. U. KRAMER
}

In 1904, H. Christ described a fern collected by C. Wercklé in Costa Rica as Saccoloma wercklei. It was listed under Saccoloma in Christensen's Index Filicum (1906); but appeared as a species of doubtful position, perhaps belonging to Ormoloma, in the Third Supplement $(1934$, p. 170). This was probably based on the authority of Maxon's comments (1933, p. 144), given in connection with his description of the latter genus. Apparently neither Christensen nor Maxon had seen the type-specimen.

When preparing a revision of the Lindsaeoid ferns of the New World (1957), I borrowed the type-specimen of S. wercklei from the Paris Herbarium, in which Christ's herbarium is incorporated, in order to ascertain whether that species did or did not belong in Ormoloma.

The type, as far as I know the only material extant, is rather poor ( $p l .13)$. It consists of two laminas with the upper parts of the petioles; the apex of one lamina is missing, and in the other it is somewhat folded and shrivelled. No rhizome is present. Nevertheless it was immediately clear that inclusion either in Saccoloma or in Ormoloma was not justified. The only species of Saccoloma in its modern, restricted sense, S. elegans, has glab. rous leaves, a rachis with two grooves on the adaxial side, separated by a more or less prominent ridge and connected with a groove on the midrib of the pinnae, and subequal, long-cuneate pinna-bases, as opposed to the hairy rachis and abaxial side of the midrib, the single adaxial rachis-groove without connection with the midribs of the pinnae (pl. 14, fig. B3) and subtruncate, more or less auriculate pinna-bases in $\boldsymbol{S}$. wercklei. Moreover, the leaf-top consists of confluent reduced pinnae, whereas in S. elegans there is a distinct free terminal pinna. The latter character, the structure of the rachis, the presence 


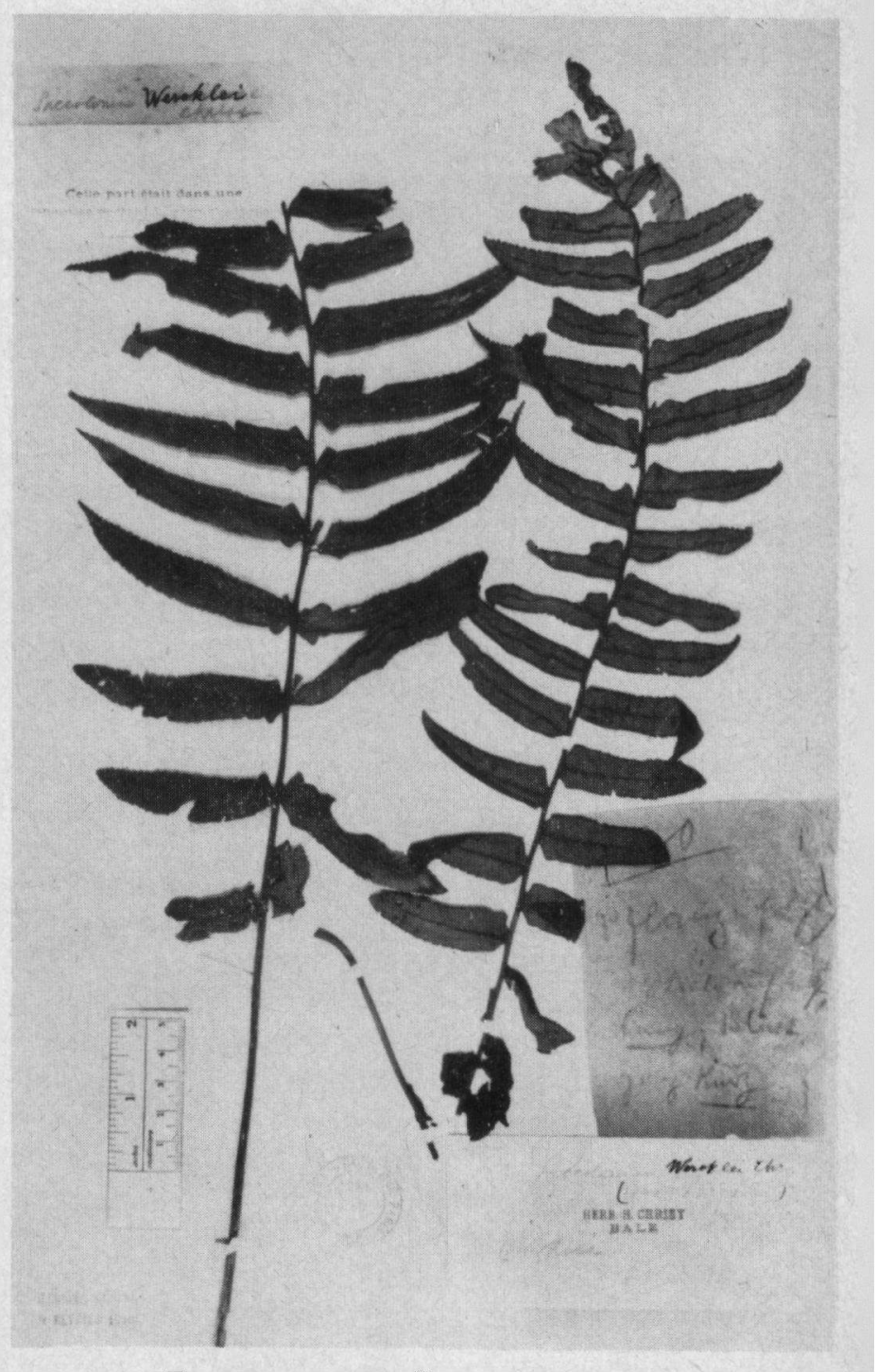

TYPE-SPECIMEN OF SACCOLOMA WERCKLEI 
of rufous articulate hairs, and the sori, which project beyond the margin, exclude $S$. wercklei from Ormoloma.

There is, however, a resemblance to the old-World fern Microlepia hookeriana (Wall.) Presl. On closer examination this resemblance proved to be more than superficial. Both species agree in their simply pinnate lamina with a few somewhat reduced basal pinnae and a rather abruptly contracted leaf-tip with confluent reduced pinnae, a single groove on the adaxial surface of the rachis with completely continuous borders, the pinnae being inserted below (that is, slightly to the abaxial side of) the edge of the groove ( $p l .13, \mathrm{fig} . \mathrm{B3}$ ), lanceolate, acute or shortly acuminate pinnae with a subtruncate base produced in a distinct auricle on the anterior and not rarely in a less pronounced auricle on the posterior side, and the presence of rufous articulate hairs. The differences may be summed up as follows:

\section{M. hookeriana}

petiole and on both sides, but esperachis cially in the adaxial groove, densely elothed with large articulate up to $2 \mathrm{~mm}$. long hairs adaxially with similar but shorter hairs, abaxially with scattered hairs (which are also found on the lateral veins)

pinnae truncate at the base, with all sessile, the posterior a very short petiolule "S." wercklei

adaxially glabrous, laterally and abaxially with a very short tomentum of articulate hairs midrib of pinnae $(<1 \mathrm{~mm}$.), except those of the leaf-apex, which are sessile

veins mostly once-forked base \pm completely adnate to decurrent, the anterior base half-free adaxially glabrous, abaxially with a similar indument as the rachis

sori intramarginal, i.e. the indusium equalling the indusium not equalling margin, fused with a the margin (Pl. II, A 2) marginal lobe to form a eup-shaped structure (Pl. II, B 2) 


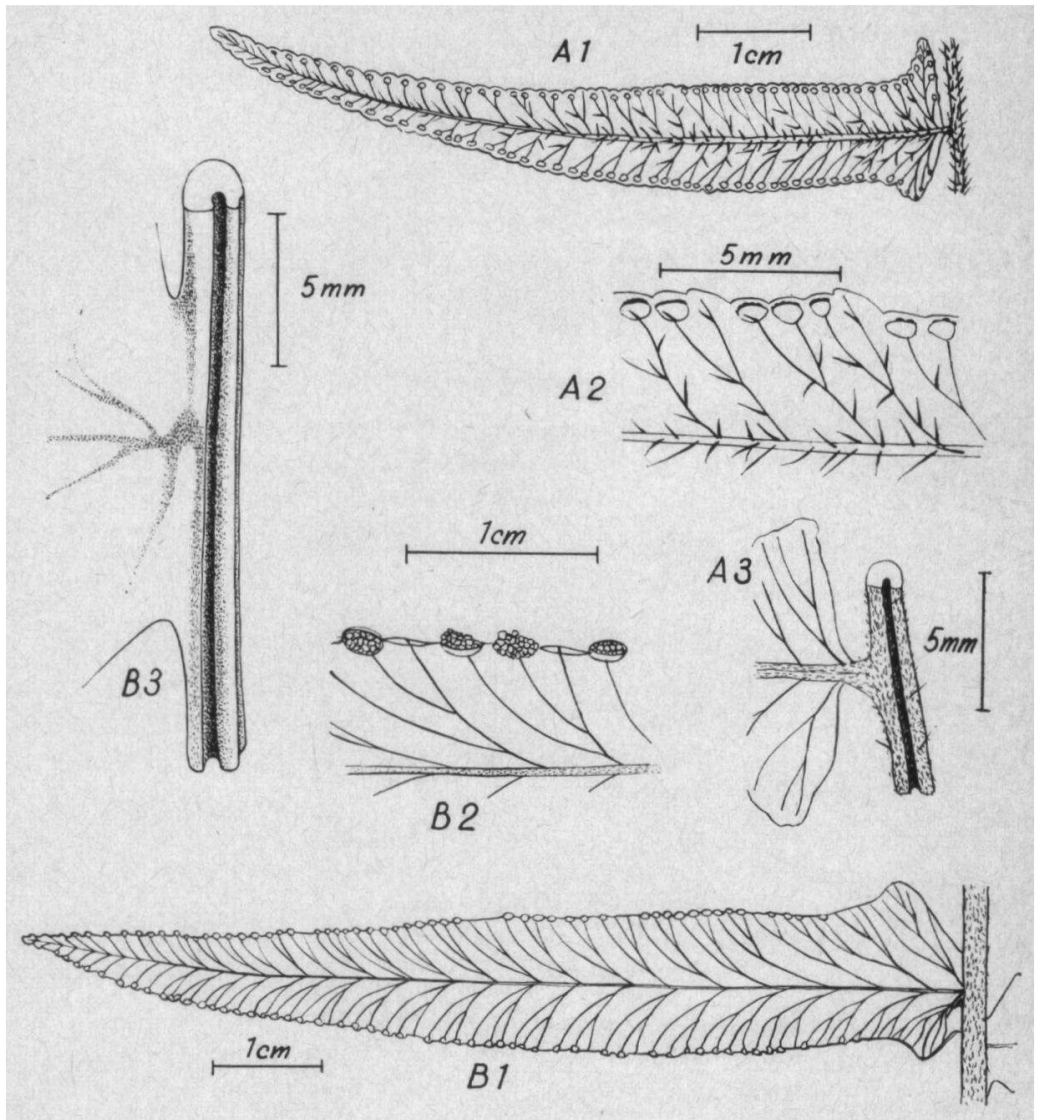

A. Microlepia hookeriana; B. Saccolonia wercklei. 1, pinna;

2, DETAIL OF PINNA; 3, JUNCTION OF PINNA WITH RACHIS 
M. hookeriana

sporangia

annulus with 18-21 indurated cells; head ca. $290 \times 225 \mu$

spores trilete, pale yellowish, smooth, da. $40 \times 28 \mu$
"S." vercklei annulus with 12-15 indurated cells; head ca. $230 \times 175 \mu$ trilete, dark brown, minutely tuberculate, ca. $30 \times 25 \mu$

In addition, the sori of $M$. hookeriana are densely paraphysate with long articulate hairs; no such paraphyses were found in "S." wercklei, but this might be due to the poor state of preservation, although it is not very likely. The indument of " $S$." wercklei consists of short, articulate hairs, though a few one- or few-celled acicular hairs with thickened walls were also present. In $M$. hookeriana, on the other hand, the bases of the hairs have thickened cell-walls.

These differences distinguish the two species without difficulty, but they are much less pronounced than the points of resemblance mentioned above, and therefore I believe that they should be included in one genus. This brings up the question in what genus they must be placed. Microlepia hookeriana occupies a somewhat isolated position in the genus, and has been made the type of a distinct genus, Scypholepia J. Smith (1875, p. 261). This was supposed to be related to Nephrolepis by reason of articulate pinnae, but there is actually no articulation at all, as was pointed out by Copeland (1947, p. 51). There is only a thickening at the base of the midrib which probably serves a mechanical purpose (a similar thickening is present in "S." wercklei, although the pinnae are adnate; it is clearly visible from the adaxial side). Rerently, however, Tagawa (1951, p. 187) defended the separation of Scypholepia from Microlepia on other grounds, namely, the frequent occurrence of an auricle on the posterior side of the pinna-base, and the open angle between midrib and veins. The second character 
I find to be of little relevancy, the difference being gradual rather than fundamental; but the first one seems to be of importance. I should like, however, to express it in a somewhat different way. In $M$. hookeriana (and in "S." wercklei) the basal lateral veins are opposite; and $I$ find it impossible to decide whether the leaf is anadromic or catadromic. The leaf-tissue extends on both sides to the same level (Pl. II, fig. B1). In all other Microlepias known to me, the leaf is distinctly anadromic, the basal vein on the anterior side being much closer to the pinna-base than the one on the posterior side, and the leaf-tissue is cut away much more strongly on this side. Possibly the presence of the swelling at the base of the midrib described above is an additional differentiating character; $I$ have not observed it in any other Microlepia. It seems to me that Scypholepia can be kept up as a subgenus or perhaps preferably as a section of Microlepia. Christensen's listing of Scypholepia under Microlepia (1906, p. xxxviii) was probably intended as reduction to sectional rank.

The following new combination becomes necessary: Microlepia wercklei (Christ) Kramer, comb. nov.

Basionym: Saccoloma Wercklei Christ, Bull. Herb. Boiss. II. 4: 1100. 1904.

TYPE: Wercklé 320 from Costa Rica, without precise locality (P!).

The following corrections and additions to Christ's deseription, besides those already referred to above, may be given :

Petiole ca. $2 \mathrm{~mm}$. in diam: Pinnae alternate or the lower ones opposite, up to $1.5 \mathrm{~cm}$. wide, chartaceous. Indusium cup-shaped, consisting of the membranous abaxial (true) indusium and a more rigid marginal lobe, the two parts completely fused; receptacle very short.

Wercklé's field-notes say "(Pflanze folgt) Stiele aufrecht, lang; Blatt ganz kurz," which probably means 
that the petiole is much longer than the lamina.

The inclusion of $\mathbf{S}$. wercklei in Microlepia may cause surprise because of the marginal position of the sori, because Microlepia is distinguished from Dennstaedtia, its closest relative, by its intramarginal sori. S. wercklei is, however, so close to Microlepia hookeriana, as shown above, that inclusion in Dennstaedtia would be highly artificial. The distinction between Dennstaedtia and Microlepia should probably be redrawn on the basis of new and more numerous characters, or perhaps altogether abandoned.

A few words may be said about the phytogeographic aspect of the relationship between $M$. hookeriana and $M$. wercklei. At first sight it may be astonishing that the closest relative of a Costa Rican fern would be found in southeastern Asia (Tagawa, loc. cit., gives the range of $M$. hookeriana as eastern India to southeastern China, Tongking, Formosa, Okinawa, to Borneo, Sumatra, and Java). Yet there are a few other examples of a more or less similar type of distribution. Loxogramme, Coniogramme, and Schaffneria each have one species in the Cordilleras of Central America and all others in southern and/or eastern Asia or in the adjacent Pacific islands. Copeland assumes that they have crossed the North Pacific. I do not know in what way this is supposed to have happened, and the solution of the problem may be more complex; but at least the phenomenon in Microlepia is not unique, and therefore the distribution does not provide an argument against our taxonomic conclusion. Incidentally, $M$. werckle $i$ is the third species of Microlepia known from the American continent, the others being the pantropic $M$. speluncae (L.) Moore and the closely allied $M$. jamaicensis (Hook.) Fée of Jamaica and Hispaniola.

I tender my sincere thanks to Mme. Tardieu-Blot, Curator of the Fern Herbarium of Paris, for the loan 
of the type of Saccoloma wercklei, to the Curator of the Rijksherbarium, Leiden, for loan of material of Microlepia hookeriana, and to Prof. R. E. Holttum for helpful advice.

\section{ReFERENCES}

CHRIST, H., 1904. Primitiae Florae Costaricensis. Filices et Lycopodiaceae III. Bull. Herb. Boiss. II. 4: 1089. CHRISTENSEN, C., 1906. Index Filicum. Copenhagen. -, 1934. Id. Third Supplement. Ibid. COPELAND, E. B., 1947. Genera Filicum. Waltham, Mass. KRAMER, K. U., 1957. A revision of the genus Lindsaea in the New World with notes on allied genera. Acta Bot. Neerl. 6: 97-290.

MAXON, W. R., 1933. Fern Miscellany III. Proc. Biol. Soc. Washington 46: 139.

SMITH, J., 1875. Historia Filicum. London.

TAGAWA, M., 1951. Fern Miscellany (5). Journ. Jap. Bot. 26(6): 185.

Botanical Museum and Herbarium, Utrecht, NethERLANDS. 